Z tajnych archiwów radzieckich (11)

MICHAŁ GNATOWSKI (Białystok)

\title{
NOWE RADZIECKIE DOKUMENTY O ANTYRELIGIJNEJ DZIALALNOŚCI WEADZ W OBWODACH BARANOWICKIM, BRZESKIM I PIŃSKIM W LATACH 1940-1941
}

\section{Wstęp}

W tomie VII „Studiów Podlaskich” opublikowałem obszerny zestaw radzieckich dokumentów przedstawiających antyreligijną działalność władz w latach 1939-1941 na północno-wschodnich ziemiach Polski. W tym zestawie uwzględniono zwłaszcza obwód białostocki. Dokumenty publikowane w niniejszym tomie są uzupełnieniem dokumentów wówczas opublikowanych i odnoszą się do obwodów baranowickiego, brzeskiego i pińskiego.

Z 9 publikowanych dokumentów 7 pochodzi z 1940 r. i 2 z 1941 r. Pierwszy nosi datę 19.05.1940 a ostatni 7.04.1941 r. Dotyczą one głównie stanu i zadaŕ antyreligijnej propagandy w wymienionych obwodach. Jedynie dokument 2 przedstawia okoliczności rekwirowania przez pracownika NKWD szafy w cerkwi w Lubczy i reakcję wierzących na ten fakt.

Obszerny merytoryczny wstęp, w którym również omówiłem zasady publikowania dokumentów, z tomu VII „Studiów Podlaskich” odnosi się także do niniejszego zestawu dokumentów.

Dokumenty publikowane są $w$ języku oryginału po raz pierwszy. Przechowywane są one w Państwowym Archiwum Obwodu Brzeskiego w Brześciu, w zespołach 7580P, 7581P, 17P. Tylko dokument $3 \mathrm{w}$ Narodowym Archiwum Republiki Białoruś w Mińsku w zespole 4 (KC KP(b)B).

W dokumentach występują następujące mniej znane skróty:

ЦК СВБ - Центральный Совет Союза Воинствующих Безбожников

ч. - - человек

ч. - - часы 


$\begin{array}{ll}\text { дер., д. } & - \text { деревня } \\ \text { др. } & - \text { другие } \\ \text { ГК } & - \text { Городской Комитет } \\ \text { г., гор. } & - \text { город } \\ \text { КО, Обком } & - \text { Областной Комитет } \\ \text { КСМ } & - \text { Коммунистический Союз Молодежи } \\ \text { м., мест. } & - \text { местечко } \\ \text { РК } & - \text { Районный Комитет } \\ \text { РО } & - \text { Районный Отдел } \\ \text { зав. } & - \text { заведуюций } \\ \text { зам. } & - \text { заместитель }\end{array}$

\title{
Dokument 1
}

1940 maj 19, (Baranowicze), - Informacja Komitetu Obwodowego LKZMB o pracy antyreligijnej wśród mlodzieży obwodu baranowickiego.

\author{
Барановическ. Обкому KII(б)Б \\ от Обкома КСM \\ Цокладная Записка
}

О проведенной антирелигиозной работе с молодежью по области

Силами лекторов обкома и отдельными РК проведено с молодежью до 50 лекций на темы:

1. О происхождении пасхи и о классовой сущности религии.

Кроме того Лекторами присланными ЦС СВБ Белоруссии прочитано 24 лекции на тему: «ІІроисхождение человека» и «Химия и религия».

Интерес молодежи к лекциям на антирелигиозные темы огромный. В каждом районе молодежь просит читать эти лекции. Лекторам задают болыне количество вопросов (по 20-30). Характерные вопросы прилагаем. ${ }^{1}$

Следует отметить, что лектора присланные из ЦС СВБ не умело отвечали на вопросы. Например лектор Купер на вопрос «Почему сам Дарвин верил в бога» ответил - «Это его недостаток». На вопрос «Может ли сейчас произойти факт преврачцения обезьян в человека», ответил «вряд ли».

Лектор читаюгий лекцию на тему «Химия и религия», на во прос «Как могло быть что Моисей ударил палкой по камню и по- 
явилась вода», - совершенно не ответил и т.д. В Василишковском районе (в сельсовете Острино), допустили к чтению антирелигиозной лекции проходимца Финкельштейна, который старался доказывать, что Христос был коммунистом???а

Значительные слои молодежи находятся под влиянием религиозников. Например в м. Новомынь подавляюцее болыпинство молодежи посешают костел. Есть два случая когда вновь принятые в комсомол (Столбцовский и Воложинский районы) подали заявлении о выходе из комсомола по религиозным мотивам.

Все это говорит о необходимости усиления антирелигиозной проиаганды. Главная трудность - нет квалифицированных антирелигиозников.

Считаем, что нужно создать областные курсы из партийно-комсомольского актива.

19/V-40r.

/Белинький/

Oryginal, rękopis.

Źródło: PAOB w Brześciu, zesp. 7580„P”, spr. 1, t. 400, k. 4 i 4b.

a Podkreślone podczas czytania.

${ }^{1}$ Brak w teczce wymienionego załącznika.

\section{Dokument 2}

1940 czerwiec 7, Baranowicze, - Informacja prokuratora obwodu baranowickiego o konflikcie $z$ wierzqcymi podczas rekwirowania przez pracownika NKWD szafy w cerkwi.

C E K P E T H O.

\section{СЕКРЕТАРЮ БАРАНОВИЧСКОГО ОБКОМА КП(б)Б TOB. $\mathrm{T}$ Y $\mathrm{P}$ y.}

22-го мая 1940 года, во время отправления религиозного культа (праздник «Никола») в Јюбчанской церкви, Начальником Јюобчанского РО НКВД был послан в церковь секретарь НКВД тов. АНДРЕЕВ производить из'ятие из церкви пюкафа. 
Когда тов. АНДРЕЕВ явился в церковь и стал забирать пикаф, присутствуюшее в церкви религиозное население - в особенности женцины в из'ятии пшкафа заявили категорическое возражения, пытаясь даже избить АНДРЕЕВА.

В этот момент в церкве перед собравпимися выступила жена свяценника, став якобы в зациту АНДРЕЕВА и заявила; «Пуская нас угнетали поляки, а болыневикам можно отдать не только пшкар, но и последнюю рубаху»

ІІосле этого собравпиеся не стали возражать и АНДРЕЕВЫМ ІІкаф был из'ят.

Мною поставлен вопрос перед Начальником УНКВД по области тов. МИСЮРОВЫМ о привлечении Начальника Любчанского РО НКВД к ответственности.

$$
\begin{gathered}
\text { ІІ Р О К У Р О Р } \\
\text { БАРАНОВИЧСКОЙ ОБЛАСТИ } \\
\text { - (podpis) - (МИХАЙЈІОВ) }
\end{gathered}
$$

7/VI-40r.

г. Барановичи.

Na górze dokumentu $\mathrm{z}$ lewej strony pieczątka firmowa $\mathrm{z}$ herbem ZSRR o następującej treści, w dwóch językach: $\mathrm{z}$ lewej w języku białoruskim i z prawej w języku rosyjskim: „Prokuratura Związku Socjalistycznych Republik Radzieckich” niżej: „Prokurator obwodu baranowickiego Białoruskiej SRR”, niżej data: 7/VI 1940 r. i niżej Nr 1/2c. (Dzień, miesiąc i nr wpisane odręcznie)

Oryginal, maszynopis.

Źródło: PAOB w Brześciu, zesp. 7580„P”, spr. 1, t. 32, k. 72.

a Wielkie litery i podkreślenie oryginału.

\section{Dokument 3}

1940 sierpieni 7, [Mińsk], -- Raport przewodniczqcego Centralnej Rady Zwiqzku Wojujqcych Bezbożników BSRR o antyreligijnych kursach przeprowadzonych w Mińsku dla lektorów i propagandystów. 


\section{СЕКРЕТАРЮ ІК КП(б) БЕЛОРУССИИ.}

Тов. МАЛИНУ. ${ }^{a}$

\section{ДОКЈАДНАЯ ЗАПИСКА.}

С 12-го июля по 6-ое августа 1940 г. Центральным Советом СВБ БССР и отделом пропаганды и агитации ILK КІІ(б)Б проведены республиканские антирелигиозные курсы подготовки лекторов и беседчиков для Западных областей Белоруссии. Материал месячной программы курсов пройден в 24 дня, увеличив занятия вместо шести до восьми часов в день, что дало возможность ускорить окончание курсов.

На курсах занималось 40 человек курсантов, прибывпиих из Западных областей, из них:

По национальности.

Белорусов ................... 19

Евреев ...................... 12

Русских .................... 4

Поляков ....................... 5

Iо партийности.

Коммунистов.............. 10

Кандидатов ...................

Комсомольцев ................ 15

Беспартийных 15
По занимаемой должности. Угителей и врачей .......... 12b Инструкторов РК КП(б)Б. 16 Работников предприятий .. 10 П р о ч и х ................. 2
По образованию. С выспим образованием ... 7 Со средним -" - _.. 16 С низгіим _-"- $\quad$-... 17

$$
\text { Мужчин - } 30 \text { ч., женпиин - } 10 \text { ч. }
$$

Как видно из вышеприведенного состава, курсанты отвечали тем требованиям, которые были поставлены курсами для подготовки лекторов и беседчиков по антирелигиозным темам, по образованию и по практическому стажу работы.

Программа курсов состояла из следуюцих тем:

1. Диалектический материализм, как философская основа воинствуюшего атеизма .................................... 12 ч.

2. Марксистско-ленинское понимание религии ................ 4 ч.

3. Борьба религиозных организаций против Великой

Октябрьской социалистической революции ................. 14 ч.

4. Униатская церковь в быв. панской Польше ................ 3 ч.

5. Религия на службе империализма ......................... 3 ч.

6. Сталинская Конституция и свобода совести ................. 6 ч. 
7. Коммунистическое воспитание и задачи антирелигиозной пропаганды .................................................... 8 ч.

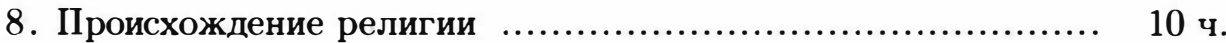

9. Религия древнего мира …..................................... 5 ч.

10. Буддизм и Ламаизм. Ислам …............................. 4 ч.

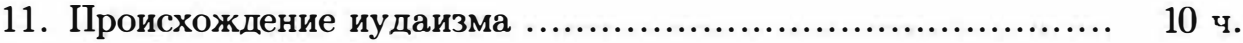

12. ІІроисхождение христианства …......................... 4 ч.

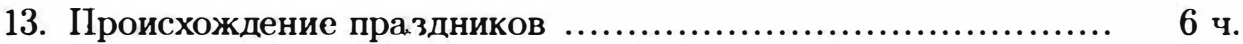

14. Средневековое христианство ….......................... 6 ч.

15. ІІроисхождение и классовая сущность католицизма ........ 4 ч.

16. Христианство в России ….................................. 8 ч.

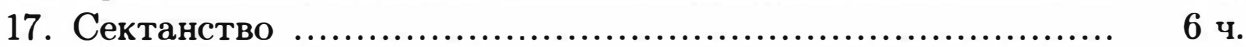

18. Основные этапы развития атеизма …...................... 4 ч.

19. Наука и религия ............................................... 8 ч.

20. Происхождение солнечной системы …................... 8 ч.

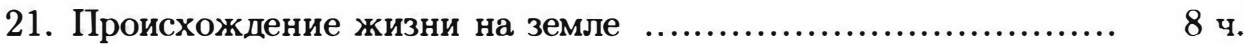

22. ІІроисхождение человека ..................................... 6 ч.

23. О душе и дупевной деятельности ......................... 4 ч.

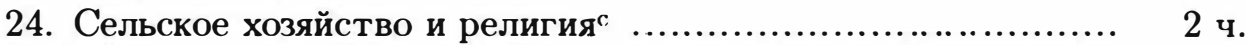

25. Организация и методы антирелигиозной пропаганды ........ 8 ч.

26. Изучение религиозных праздников ........................ 9 ч.

ВСЕГО 160 час.

Курсы были обеспечены высококвалифицированными лекторами антирелигиозниками по составу: профессоров - 2 , доцентов - 4 , научных работников - 2. Тема диалектический материализм как основа воинствуюшего атеизма прочитана лектором ЦК ВКІІ(б) тов. КОЛОВИЦКИМ.

Для закрепления проходимого материала с курсантами проведены экскурсии в музей революции, исторический музей и дан доклад О международном положении. Все курсанты при окончании курсов обеспечены антирелигиозными библиотеками из книг: «Антирелигиозный учебник», Ленин «О религии», Ярославский - «Задачи антирелигиозной пропаганды», Федосеев - «Как возникло человеческое обшество» и др., а также выдано две методразработки на темы: «Церковь в панской ІІольше», «Летние и осенние религиозные праздники».

Одновременно в целях оказания практической помоци курсантам, в процессе работы курсов былю поручено более подготовленным курсантам написать лекции на темы: «Церковь в панской ІІолыше», «Дарвинизм и религия», «Происхождение жизни на земле», «Происхождение 
христианства» и другие. Лекции были зачитаны на последуюгцих занятиях. ${ }^{\mathrm{d}}$

По окончании курсов, квалификационной комиссией и проведенной проверкой курсантов, установлены следуюлцие результаты работы курсов по успеваемости: рекомендованы лекторами - 19 чел., беседчиками - 20, прослупнал курсы 1.

ПРЕЦСЕЛАТЕЛЬ ЦС СВБ БССР. (podpis) (ЛАГУТЕНКО)

7/VIII-40 г. ${ }^{\mathrm{e}}$

Oryginal, maszynopis.

Źródło: NARB w Mińsku, zesp. 4, spr. 3, t. 1646, k. 77-78.

a Wielkie litery i podkreślenia oryginału.

b Słowo „lekarzy” i liczba „12” wpisane odręcznie. Niżej liczba „3” poprawiona na liczbę "2".

c Słowa „i religia” wpisane odręcznie.

d Słowa: ,i inne. Wykłady zostały wygłoszone w czasie dalszych zajęć” wpisane odręcznie.

e Data wpisana odręcznie.

\section{Dokument 4}

1940 październik 10a , [Pińsk], - Raport Komitetu Obwodowego KP(b)B $w$ Pińsku o stanie antyreligijnej propagandy $w$ obwodzie.

COBEPШEHHO CEKPETHO $^{\mathrm{b}}$

ЦК КП(б) БЕЛОРУССИИ

тов. МАЛИНУ.

$$
\text { Д ОК Л А Н А Я } 3 \text { А П И С А }
$$

О состоянии антирелигиозной работы по ІІинской области.

В ІІинской области за период с января по сентябрь месяц прочитано на антирелигиозные темы 47 лекций, которыми охвачено 8300 человек. Лекции читались главным образом в г. Пинске и районных центрах на следуюцие темы: «Наука и религия», «Марксизм и религия», «Религия 
и свобода совести», «Сталинская Конституция и свобода совести» и другие.

Популярные массовые лекции по антирелигиозным вопросам среди пиирокого населения и особенно в деревне не получили распространения, это объясняется некоторой боязнью партийных организаций, что бы не затрагивать религиозные чувства веруюцих и с другой стороны отсутствием подготовленных кадров антирелигиозников.

$\mathrm{K}$ лекциям, докладам и беседам по антирелигиозным вопросам проявляется исключительный интерес трудяцихся, об этом свидетельствуют такие факты: В Давид-Городке на лекции «Сталинская Конституция и свобода совести» присутствовало 250 человек, на Микашевичском фанерном заводе № 1 -- 220 человек, местечко Ленино - 175 человек.

За последнее время в областной газете «ІІолесская Правда» и районных газетах «Авангард», «Крестьянская правда» и «Чырвоная Зара» было опубликовано ряд статей по антирелигиозным вопросам. Однако, антирелигиозная работа среди трудяцихся области поставлена далеко неудовлетворительно.

О слабой постановке антирелигиозной работы в области свидетельствуют следуюцце факты:

В м. Телеханы того-же района до последнего времени открыта работа «Хэдер» с количественным составом людей - 30 чел. допкольного и шикольного возраста. ІІартийная организация и Районо с работой «Хэдера» мирилась и принимала это за должное, только вмешательство Обкома КІІ(б)Б положило конец суцествованию этой пиколы.

В Ганцевичах за контрреволюционную агитацию был арестован ксендз. Секретарю Райкома Партии явилась делегация веруюцих с требованием отпустить ксендза, но не получив положительного результата, польская молодежь в ответ на это перестала участвовать в обцественно-массовой работе. Вышла из кружков художественной самодеятельности, перестала посешать клуб. Через три дня приехал в район новый ксендз.

В Телеханах, в одной еврейской семье родился сын. Равин с двумя служителями культа подкараулили отсутствие мужа, явились на квартиру и стали требовать произвести обрезание. Получив категорический отказ, они пытались действовать угрозами и только репительный протест мужа предотвратил эту попытку обрезания.

Некоторая религиозная часть евреев все еще не работает по субботам (артель «ІШвейник» - м. Телеханы).

Были факты, когда население требовало перевода костела в цер- 
ковь, поскольку в свое время это была церковь.

С отсутствием проведения должной политико-массовой и антирелигиозной работы в ряде случаев наблюдается активизация духовенства. Как например: в ІІинском железно-дорожном клубе за последнее время посещаемость молодежи резко сократилась.

Молодежь стала активно посеццать костел.

Среди отдельных работников, приехавших на работу из восточных областей, имеет место исполнение религиозных обрядов. Жена коммуниста тов. Гаврученко с приездом в Ивановский район стала активно посещать церковь, в результате причастилась сама и причастила своих детей.

Отдельные руководяцие работники области и района совершенно неправильно и политически неверно подходят к разрешению религиозного вопроса. Зав. Облкоммунхозом тов. Масианским было дано указание забрать костел под склад для зерна. Исполнение этого распоряжения не вошло в силу, Горком КП(б)Б т. Масианскому объявил выговор.

Олин из работников НКВД Лунинецкого района вместе с Зав. военным отделом РК КП(б)Б зашли к попу, выпили и стали уговаривать попа, чтобы он отрекся от сана.

Осенние еврейские религиозные праздники в отдельных случаях повлекли за собой нарушение Указа ІІрезидиума Верховного Совета CCCP от 26/VI-1940 года.

В Павид-Городке на судоверфи один старик еврей отказался выполнить работу 3-го Октября и ушел домой. В еврейской пшколе (Давид-Городок) в этот день не явилось в пюколу $10 \%$ всех учащихся, что составляет 36 человек. В отдельных еврейских школах области в дни еврейских религиозных праздников ученики хотя и явились в пІколу, но отказывались писать на уроках.

Районная партийная организация Ленинского района обратилась в Обком KII(б)Б с запросом, как поступить с костелом и можно ли использовать это помешение под культурное учреждение.

В пограничном местечке Ленино в свое время польские власти построили костел для обслуживания главным образом пограничной охраны и семей офицерства. С приходом Красной армии последний перестал сушествовать, ксендз бежал. Іомешение костела не используется и пустует. Польского населения и людей ка'голического вероисповедования в местечке всего 3 человека.

Такое-же положение в Давид-Городке. Костел здесь был построен 
в 1936 году и предназначаліся к обслуживанию соллат батальона (познанцев пограничных войск), офицеров с семьями и чиновничества.

С первых дней Советской влгасти функционирование костела прекратилось, помецение является броссовым и неиспользуется по назначению. Польского населения в городе 119 челювек, из них: соверпеннолетних 70 человек. Ксендз сбежалі в феврале 1940 года.

Помещения костелов в Ленино и Давид-Городке пелесообразно использовать под кино-театры.

Имеются случаи, когда сами веруюшие отказываются от помецений. Например в Пинске к секретарю Горкома КП(б)Б явилась делегация веруюцих евреев с просьбой взять у них две синагоги, так как они не в состоянии платить налоги. Всего синагог в Пинске 43.

Здесь идет реть о двух так называемых хоральных синагогах, которые раныше находились на содержании купечества, куда покупались места. Теперь этой «знати» нет и население категорически отказывастся содержать синагоги.

В городе Пинске имеется два полуразрушенных церковных зданий (костел и церковь). Вид их портит всю вненность центральной части города. Церковный и костельный советы отказываются принимать какие-либо меры для приведения их в порядок, так как это связано с огромными денежными затратами.

Эти здания вполне можно приспособить при соответствуюгих денежных вложениях под культурные учреждения (кино и театр), в которых город крайне нуждается.

По всем этим вопросам желательно получить раз'яснение.

В целях поднятия антирелигиозной работы в области, Обкомом партии обрашено внимание районных комитетов партии на необходимость антирелигиозной работы в районах.

Отдел пропаганды и агитации Обкома КП(б)Б расширил тематику антирелигиозным вопросам лекторской группы.

Для чтения антирелигиозных лекций, бесед и докладов привлечены пाтатные лектора из партийного и комсомольского актива и интеллиигенции города.

Со своей стороны Обком КП(б)Б считает целесообразным организацию в Западных областях ячеек Союза Воинствуюлих Безбожников.

№ 384

$10 / \mathrm{X} 40^{\mathrm{c}}$
СЕКРЕТАРЬ ПИНСКОГО ОБЛАСТНОГО КОМИТЕТА КП(б)Б ПО ПРОПАГАНДЕ (podpis) (И. УЛАЗОВ) ${ }^{1}$ 
Oryginal, maszynopis.

Źródło: PAOB w Brześciu, zesp. 7581 „P”, spr. 1. t. 19, k. 219-223.

${ }^{a}$ Data kancelaryjna wysyłki dokumentu do KC KP(b)B.

b Wielkie litery i podkreślenia oryginału.

c $\mathrm{Nr}$ i data wpisane odręcznie.

${ }^{1}$ Iwan Andrejewicz Ułazow, ur. w 1906 r., narodowości rosyjskiej. Do 1939 r. pracował w Wyższej Szkole Propagandystów KC KP(b)B jako kierownik wydziału nauczania. Od listopada 1939 sekretarz ds. propagandy Komitet u Obwodowego KP(b)B w Pińsku.

\section{Dokument 5}

[1940 październik], [Baranowicze], - Raport o stanie antyreligijnej propagandy $w$ obwodzie baranowickim.

\section{О СОСТОЯНИИ АНТИРЕЈИГИОЗНОЙ ІІРОІІАГАНДЫ В БАРАНОВИЧСКОЙ ОБЈАСТИ ${ }^{a}$}

Антирелигиозная пропаганда по нашей области за последнее время несколько улучшилась. За этот год лучшими силами прочитано около 157 лекций, 459 докладов и ряд бесед на разные темы. На лекциях присутствовало 14758 человек, на докладах присутствовало 51408 человек. ${ }^{\text {b }}$

50 лекций прочитано на темы: «ІІроисхождение пасхи», «Классовая суцность религии». 31 лекция прочитана на темы: «Іроисхождение вселенной», «ІІроисхождение жизни на земле» и т.д.

Јекцию «О происхождении человека» в гор. Барановичи на Мясокомбинате, в институте читал лектор ЦК СВБ тов. ГРАНТ.

Научный работник минского мединститута тов. САЈІОГУБ прочитал в Барановичах 7 лекций на тему: «Химия и религия».

Јектор Барановичского Обкома КII(б)Б тов. БЕЈІЕНЬКИЙ в районах и на предприятиях гор. Барановичи прочитал ряд лекций на тему: «Классовая суццость религии».

Јектор ЦС СВБ БССР тов. ІІОНАСЕВИЧ прочитал в районах 10 лекций на тему: «Строение и превращение вецества». На всех епо лекциях присутствовало 1.982 человека.

Јектор ЦС СВБ БССР професор ЈЫНОВСКИЙ читал лекции на Барановичском лесзаводе, на курсах работников суда и прокуратуры 
и других коллективах города на темы: «ІІроисхожление свету», «IІроисхождение жизни на земле».

ІІредседатель ЦК СВБ БССР тов. ЈІАГУТЕНКО на предприятиях гор. Барановичи и в некоторых районах прочитал 11 лекций на тему: «Церковь и государство». ІІрочитанной лекцией тов. ЈІАГУ'ГЕНКОМ в гор. Слониме слушатели остались недовольны. Крестьяне спросили у него, «Как створена земля». ЈІАГУТЕНОК ответил: «Ну как Вы думаете где бог мог взять столько земли».

В зельвенском районе на антирелигиозные темы прочитано 8 -- лекций, читал их зав. отделом щропаганды и агитации РК КІІ(б)Б т. РАДЧЕНКО.

В Клецком районе прочитано 11 лекций на темы: «Церковь и религия», «Гроисхождение человека» и др. Читали лекции подобранные Райкомам партии т.т. І ЕНЗБЕР и IIIIАКОВСКИЙ.

На предприятиях и учреждениях гор. Барановичи прочитана 41 лекция на темы: «Химия и религия», «Строение мира и происхожление солнечной системы» и др. На лекциях присутствовало 3.200 человек. Јекции, доклады, беседы проводились во всех районах области.

IIo 12 районам нашей области для читки лекций и докладов на антирелигиозные темы подобрано 21 человек. Например в Новогрудском районе читает лекции на антирелигиозные темы т.т. TECJIEHOK (директор школы), КУІІІЈІЕВСКИЙ (преподаватель педучилипца). В ЈІяховичском районе читают лекции учителя т.т. БЫТЕНЬСКИЙ, (учитель Островской НСШ), ТУКАЙ (Каньковская НСІІІ Федековского с/совета), IIITУНДЕРА (IIІевелевская НСІІІ). В Радуньском районе читают секретари РК КІІ(б)Б тов. КАЦНЕЈЬСОН и РК ЈІКСМБ тов. СОФИЕНКО. В Воложинском районе читают лекции делают доклады на антирелигиозные темы зав. отделюм пропаганды и агитации PK KII(б)Б тов. НАРУЦКИЙ и зав. парткабинетом тов. НИСИНБАУМ. В Ивьевском районе лекции читают учителя т.т. ТРОЯІІЕВИЧ, ОМЕЈЬЯНЮК.

Для проведения лекций и докладов на антирелигиозные темы 10 человек из числа областного, партийного и безпартийного актива при ЦС СВБ БССР прослушали месячные курсы. Кроме того Обкомом комсомола проведен однодневный семинар более подготовленных агитаторов с расчетом, что бы эти товарици проводили беседы на антирелигиозные темы. На семинаре присутствовало 30 человек.

Во время докладов, лекций слушатели задают много вопросов. Вот некоторые из них: «ІІочему в Рыме богачи преследовали христианство, 
которое зашищало их интересы», «Сушествовал ли когда нибудь Христос»с, «ІІчему Вы заинтересованы, что бы не было веруюицих» и др.

На ряду с положительными имеются и отрицательные моменты в постановке антирелигиозной пропаганды. Отдельные лектора неправильно отвечали слупателям на зацанные им вопросы. Так например: Јектор ЦС СВБ БССР тов. КУІІЕР на вопрос «Почему сам Дарвин верил в бога» ответил - «Это его недостаток». На вопрос «Может ли сейчас произойти факт очеловечения обезьяны», ответил «Вряд лии».

В Стрелянском с/совете Дятловского района отлельные комсомольцы в течении одной ночи вырвали стояшие по перекресткам кресты (12 штук). В этом же с/совете и районе группа баптистов не только не хотела сама здавать хлебозаготовки, но и проводили работу среди крестьян, что бы послецние не здавали хлеба.

В местечке Радунь (этого же района) во время летних каникул ксендз собиралг к себе ребят и читалі им «закон божий».

В Городипенском районе Дупковского с/совета в деревне Нестери крестьянин ХОМА ИВАН после приглапения его на совешание уполномоченных по подписке на заем заявил: «Мне некогда быть на совешании, я должен идти в церковь». Причем тут же передал записку в которой написал: «На совешании присутствовать не могу потому, что будет проводиться в еврейском доме молитва отцу небесному. Там нельзя курить, плевать, так как этот дом свяшенный».

По области в феврале месяце было два случая, что вновь принятые в комсомолг (в Столбцовском и Воложинском районах) выбылии из комсомола по религиозным мотивам.

Во время проводимых лекций, докладов прямых выступлений в защиту религии не было. В отдельных случаях бросались реплики «А всеже бог есть». Такие реплики были в колхозе им. СТАЛИНА Запольского с/совета Јюбчанского района, на Мясокамбинате (в гор. Барановичи).

В населенных пунктах с болыним количеством католиков заметно сильное влияние ксендзов. Особенно заметно это влияние в Н. Мыпском с/совете этого же района, завод «Неман», где на лекцию лектора ЦС СВБ БССР тов. ПОНАСЕВИЧА из польского населения явилось только несколько человек.

Для налаживания антирелигиозной пропаганды необходимо усилить воспитательную работу среди населения. Нужно больше читать лекций, докладов на антирелигиозные темы (лектора-цокладчики долюжны быть хорошо подготовленными).

Журнал «Спутник Агитатора», «Болышевик Белоруссии», цен- 
тральные, областная и районные газеты должны болыне помешать материала на антирелигиозные темы.

Очень хорошо было бы, если бы в Западные области БССР было направлено ряд кинокартин, разоблачаюгци контрреволюционную суцность религию.

Создовать руководяшие органы СВБ в сельских местностях западных областей еце рано, потому, что народ еце неподготовлен к этому. Их можно организовать в городах, на крупнейних предприятиях где болєе проведено соответствуюцей работы в этом направлении.

\section{СЕКРЕТАРЬ БАРАНОВИЧСКОГО ОБКОМА КП(б)Б (ОСТРОВСКИЙ $)^{2}$}

Kopia, maszynopis.

Źródło: PAOB w Brześciu, zesp. 7580,„P”, spr. 1, t. 400, k. 49-52 (obustronne).

a Wielkie litery i podkreślenie oryginału.

b Liczby "157" i ,459" oraz ostatnie zdanic akapitu wpisane odręcznie.

c Kolejne pytanie wykreślone $\mathrm{w}$ oryginale dokumentu.

1 Pomyłka, w Związku Wojujących Bezbożników istniała Centralna Rada, a nie Komitet.

2 Borys Chaimowicz Ostrowskij, ur. w 1911 r., narodowości żydowskiej, wykształcenie średnie. Do objęcia funkcji sckretarza Komitetu Obwodowego KP(b)B w Baranowiczach był zastępcą Kierownika Wydziału Agitacji i Propagandy Komitetu Obwodowego $\mathrm{KP}(\mathrm{b}) \mathrm{B}$ w Mohylowie.

\section{Dokument 6}

[1940 październik], (Baranowicze], - Projekt Uchwaly Biura Komitetu Obwodowego $K P(b) B w$ Baranowiczach $w$ sprawie rozwijania antyreligijnej propagandy $w$ obwodzie.

Пролетарии всех стран, Соединяйтесь!

Проект $^{\mathrm{a}}$

ІІостановление

Бюро Барановического обкома КП(б)Б от ... 40 года

О развертывании антирелигиозной пропаганды по области.

Бюро обкома отмечает, что по области проведена болыная антирелигиозная работа. За 1940 год прочитано 50 лекций на темы: «О про- 
исхождении пасхи», «О классовой сушности религии». Кроме того прочитана 31 лекция на темы: «Происхождение человека» и «Химия и религия». ПЈ городу Барановичи о контрреволюционной сущности пасхи населению сделано 18 докладов. Почти во всех районах области в связи с пасхальными днями проведены доклады, беседы на антирелигиозные темы.

Интерес населения к лекциям, докладам на антирелигиозные темы огромный. В каждом районе население просит читать лекции на антирелигиозные темы. Вся поступаюцая антирелигиозная литература в магазины Когиза сразу же раскупается.

Однако бюро обкома $\mathrm{KII(б)Б} \mathrm{отмечает,} \mathrm{что} \mathrm{антирелигиозная} \mathrm{про-}$ паганда по области находится в неудовлетворительном состоянии. До сих пор не имеется областного руководства союза воинствуюших безбожников. Отсутствуют руководящие органы союза воинствуюших безбожников в Василипгковском, Зельвенском, Барановическом, Новогрудском, Столбцовском и др. районах. На предприятиях, учреждениях, совхозах и колхозах не организованы ячейки СВБ. Отдельные лектора не правильно отвечали слупателям на вопросы. Так например Лектор присланный из ЦС СВБ тов. Купер на вопрос «Почему сам Царвин верил в бога» ответил - «Это его недостаток». На вопрос «может ли сейчас произойти факт превращения обезьяны в человека» ответил «Вряд ли» и др.

Совсем мало помешают материалы на антирелигиозные темы областная и районные газеты. Столбцовская районная газета «Голас Селянина» за 1940 г. поместила только 1 заметку, Несвижская райгазета «Чырвоны Стяг» поместила 1 заметку, газета Слонимского района «Вольная IІраца» поместила 3 заметки с начала года и т.д. В связи со слабой постановкой антирелигиозной работы по области есть два случая когда вновь принятые в комсомол (в Столбцовском и Воложинском районах) подали заявление о выходе из комсомола по религиозным мотивам.

Бюро обкома КП(б)Б постановляет:

1. Отделу кадров обкома в ближайшие дни подобрать товарицей для областного руководства союза воинствуюших безбожников с тем, чтобы на очередном бюро обкома утвердить их.

2. ІІредложить Барановическому ГК КІІ(б)Б, Василипгковскому, Новогрудскому, Зельвенскому, Столбцовскому и др. PK КІІ(б)Б до 15 июня 40 г. организовать районные руководяпие органы союза воинствуюших безбожников. ГК и $\mathrm{PK} \mathrm{КП(б)Б} \mathrm{в} \mathrm{ближайшее} \mathrm{время}$ 
на предприятиях, учреждениях совхозах и колхозах созцать ячейки

СВБ, широко развернув антирелигиозную работу среди населения.

Обязать секретаря Обкома комсомола тов. Масарского и председателя юблпрофсовета тов. Степанова усилить антирелигиозную работу среди членов Союза и молодежи, привлекая для читки лекций, докладов и бесед лучшие научные силы имеюпиеся в области.

Редакциям облас:тной и районных газет систематически помецать статьи, заметки на антирелигиозные темы, которые помогли бы насе лению освободиться от религиозного дурмана.

Oryginal, rękopis.

Źródło: PAOB w Brześciu, zesp. 7580,P”, spr. 1, t. 400, k. 1-3.

a Podkreślenie oryginału

\section{Dokument 7}

[1940 październik], [Lachowicze], - Raport Komitetu Rejonowego KP(b)B $w$ Lachowiczach o stanie antyreligijnej propagandy $w$ rejonie.

\section{БАРАНОВИЧСКИЙ ОБКОМ КП(б)Б}

\section{ОТДЕЛ АГИТАЦИИ И ПРОПАГАНДЫ}

\section{ДОКЛАДНАЯ ЗАПИСКА.}

О состоянии антирелигиозной работы по Ляховичскому району

Силами агитаторов коммунистами, комсомолыцами и некоторыми из беспартийного актива проведено 35 бесед на темы о происхождении пасхи и об отделении церкви от государства, прочитано 3 лекции на темы «Происхождение челювека и классовая сущность религии».

В докладах и беседах о дне 1-го мая и на другие темы проводимых агитаторами увязывались вопросы антирелигиозного характера.

Во время избирательной капании по выборам в Верховный Совет СССР и БССР на занятиях кружков было уделено внимание антирелигиозным вопросам. В дни религиозных праздников в школах проводились беседы с детьми на антирелигиозные темы но нужно отметить, что среди учителей есть еще много элементов религиозного настроения. Например учитель Ляховичской НCIII № 1 Цибульский ходит 
в костел и играет на арганах, учитель Даревской пикоы Бубен (сейчас уволен) ходит в костел и пытается втягивать туда детей. ${ }^{b}$ Есть и учителя, которые проявили себя в обцественной работе (руковоцят кружками самодеятельности, участвуют в агит массовай работе) и проводят антирелигиознуг работу как в пюколах среди детей так среди населения. К таким учителям можно отнести т. Бытенского Островская HCII, Тукай Каньковская нач. пкола Федкковского с/с, IIтундера IIIевелевская НСІІ и других.

Антирелигиозная пропаганда в нашем районе все таки недостаточно развернута. Районного руководства союза воинствукиих безбожников еще не имеется. Ячейки СВБ не организованы. ІІартийной организацией напего района обрашено внимание религиозной пропаганде. В ближайпие дни будет создано новое руководство СВБ и будут организованы ячейки СВБ.

\section{Зав. отдела агитации и пропаганды РК КП(б)Б (podpis) (Свяридович) ${ }^{1}$}

Oryginal, maszynopis.

Źródło: PAOB w Brześciu, zesp. 7580,P”, spr. 1, t. 400, k. 22.

a Wielkie litery oryginału.

b Podkreślenia dokonane w trakcie czytania w Komitecie Obwodowym KP(b)B w Baranowiczach.

1 Fiodor Tichonowicz Swiaridowicz, ur. w 1902 r., narodowości białoruskiej, wykształcenie średnie. Od 18 III 1941 r. sekretarz ds. kadr KR KP(b)B w Lachowiczach.

\section{Dokument 8}

1941 styczeń 27, [Pińsk], - Uzupelnienie do raportu o stanie antyreligijnej propagandy $w$ obwodzie pińskim.

\section{ОТДЕЛУ ПРОПАГАНЦЫ И АГИТАЦИИ ЦК КП(б)Ба}

Іополнительный материал к докладной записке по антирелигиозной работе.

В ГІинской области имеется 126 церквей, 26 костелов и 75 синогог с общим количеством служителей религиозных культов 167 человек, в том числе попов 109 , ксендзов 26 и 32 раввина. 
В Солинском и Јенинском районах имеется 6 молитвенных домов бобтистов.

ІІроводимая антирелигиозная работа все больше и больше способствует отходу веруюцих от религии.

В деревне Клементиново, Горбахского сельсовета, Ивановского района у крестьянина ІІІилю Д. умер отец, он похоронил его без попа.

«При польской власти, -- говорит ІІІило, - хоронить без попа не разреплалокь, за это пाтрафовали».

Резко сократилось число верующих в Денисковичском сельском совете, Ганцевичского района.

ІІоп Дончик Ф. деревни Язвинки, Јунинецкого района отрекся от сана. Служители религиозных культов Телехановского района поп - Тридентский Г., псаломцик - Наумов, раввин - Бурштейн А. отреклись от сана.

Колхозник колхоза «17-го сентября» Колонского сельсовета, Телеханского района Собко Л. в прошлом активный посетитель церкви - певчий, в настояцее время является одним из лучших агитаторов, перестал посеццать церковь и ведет антирелигиозную работу в своей деревне.

Еврейское население города ІІинска обратилось в Горисполком с просьбой взять у них несколько синогог, т.к. они не в состоянии плотить налоги. В результате проводимой антирелигиозной работы уже собрано свыпе 2000 подписей, ведется дальнейпая работа.

Молодежь деревни Охово, Жабчицкого района пришла в Райком партии и рассказала, что поп агитирует их за посешение церкви, одновременно они спросили можно ли им удовлетворить просьбу попа и спеть «Катюшу» в церкви. Эта молодежь, кроме того, спросила сделать в деревне Охово доклап на антирелигиозную тему. ГІо их просьбе секретарь PK КІІ(б)Б тов. Силков сделал доклад на тему: «ІІроисхождение религии», на котором присутствовало около 200 человек. Доклад был прослушан с болыним вниманием.

Ярким примером отхода веруюцих от религии свидетельствует рапорт священника IIІапко. (прилагается) ${ }^{1}$.

Для антирелигиозной работы привлекаются кадры из местного партийно-хозяйственного актива. Директор Столинского сельско-хозяйственного техникума тов. Клименко читает лекции на тему: «Iроисхождение жизни на земле». Зав. учебной части этого-же техникума т. IIІарунич читает на тему: «ІІроисхождение солнечной системы».

Доклады на антирелигиозные темы читают: директор Јенинского 
лесхоза т. Титов, секретарь редакции газеты «Авангард» т. Журавский и .др.

Кроме этого в районах читались лекции лекторами Центрального Совета Союза Воинствуюших безбожников Белоруссии т.т. Марьясин, Теможевский, Сидоренко и др.

Всего в области прочитано 171 лекций и докладов по антирелигиозным вопросам, которыми охвачено 27416 человек.

В ряде районов и деревень области служители религиозных культов проводят сбор денег, читают проповеди, разжигая ими религиозные чувства веруюцих.

В деревне Бостынь, Јунинецкого района поп Вечерко В. в церкви проводит среди крестьян работу, чтобы последние оказали ему помощь в уплате налогов. Для этой цели был выделен специальный человек, которому поручено производить сбор по 10-15 рублей с каждого крестьянского двора.

В деревне Јунин, Јунинецкого района, тот-же поп Вечерко 7 ноября в день демонстрации пытался выступить с обрашением к крестьянам, чтобы они помогли оплотить ему налюги, но последнему не дали возможность выступить.

ПІоп деревни Доброславко, ЈІогишинского района, ведет пропаганду среди веруюших, что между религией и социализмом есть общее, родственное. Лозунг: «Кто не работает, тот не ест» заимствован болышевиками из евангелии.

Факты враждебной деятельности имеют место в Јенинском, Ивановском, Давид-Городокском и др. районах.

$27 / 1-41$ г.

\section{ЗАМ. ЗАВ. ОТДЕЛА ПРОПАГАНДЫ И АГИТАЦИИ ПИНСКОГО ОБКОМА КІІ(б)Б. - (БИКАІІОВ $)^{2}$}

Исх. № 71c

$27 / \mathrm{I} 1941$ г. ${ }^{\mathrm{b}}$

Kopia, maszynopis.

Źródło: PAOB w Brześciu, zesp. 7581 „P”, spr. 1, t. 70, k. 36-38.

a Wielkie litery oryginału.

b $\mathrm{Nr}$ i data wpisane odręcznie.

$1 \mathrm{~W}$ teczce brak tego dokumentu.

2 Pietr Jefimowicz Bikaszow, ur. w 1902 r., wykształcenie średnie. Od 15 X 1940 r. zastępca Kierownika Wydziału Agitacji i Propagandy KO KP(b)B w Pińsku. 


\section{Dokument 9}

1941 kwiecień 7, [Brześć], - Uchwala Biura Komitetu Obwodowego KP(b)B $w$ Brześciu o stanie antyreligijnej propagandy $w$ hajnowskim $i$ antopolskim rejonach.

\section{C e K pe Tн.$^{\mathrm{a}}$}

Б- $66 / 3$

11/IV-1941 г.

От 7 апреля 1941 года.

О СОСТОЯНИИ АНТИРЕЛИГИОЗНОЙ ПРОПАГАНДЫ И АГИТАЦИИ В ГАЙНОВСКОМ И АНТОПОЈЬСКОМ РАЙОНАХ.

Бюро Брестского Обкома KII(б)Б отмечает, что Гайновский и Антопольский Райкомы KII(б)Б не уделяли достаточного внимания постановке антирелигиозной пропаганды и агитации в районе. Лекции и доклады, как одна из важнейпих форм антирелигиозной пропаганды проводились не систематически и читались главным образом в районных центрах, а в деревнях и селах района антирелигиозная работа по сушеству не начата.

В результате чего, имеются факты оживления враждебной деятельности церковников и религиозных сект (дер. Анисковичи, Осиповичи Антопольского района, Мала-Наревка - Гайновского района).

Райкомы КП(б)Б не занимались вопросом подбора и выращивания антирелигиозного актива из местного населения и не привлекали к активной антирелигиозной работе интеллигенцию - врачей, учителей, агрономов и других.

Бюро Обкома КП(б)Б - п о с т а н о в л я е т:

1. ІІредложить Гайновскому и Антопольскому РК КП(б)Б организовать среди населения повседневную, систематическую, антирелигиозную пропаганду и агитацию.

Основной формой антирелигиозной пропаганды должно быть систематическое чтение лекций и докладов на антирелигиозные темы, построенных на естественно-научном материале, а также проведение индивидуальной антирелигиозной пропаганды.

Антирелигиозная пропаганда, как одна из форм коммунистического 
воспитания, должна быть наступательной и охватывать все слои населения рабочих, служалцих, колхозников и трудяшихся единоличников, интеллигенцию (учителей, врачей, агрономов и т.д.).

2. Обязать Гайновский и Антопольский райкомы КП(б)Б создать при парткабинетах семинар по повыпению теоретического уровня пропагандистских кадров антирелигиозников, установив проведение занятий семинаров не реже одного раза в месяц. Для руководства семинара подобрать наиболее подготовленных товарицей из числа квалифицированных пропагандистских и педагогических кадров района.

Іля более ппирокого охвата систематической учебой и подготовки антирелигиозного актива агитаторов из местного населения организовать при домах соцкультуры, избах-читальнях, педкабинетах и нюколах антирелигиозныс кружки, вовлекая в них коммунистов, комсомольцев и беспартийный актив, обеспечив регулярное проведение занятий кружков не реже 2 раз в месяц. ${ }^{\text {b }}$

IІоручить отделу пропаганды и агитации Обкома КП(б)Б разработать тематику по антирелигиозным вопросам для проведения занятий в семинарах и кружках.

3. ІІредложить Гайновскому и Антопольскому РК КП(б)Б организовать в культпросветучреждениях и пколах выставки: литературы, отдельных статей из газет и журналов, наглядных пособий. ПІроводить антирелигиозные вечера вопросов и ответов.

4. В связи с предстоящими религиозными праздниками (еврейская, польская и христианская пасхи) церковники и сектанские проповедники особенно будут усиливать деятельность и всячески будут пытаться организовать массовые пьянки, праздничные и послепраздничные прогулы и другие религиозные обряды направленные на подрыв социалистической дисциілины труда на предприятиях и срыв весеннего сева в деревне. Обязать Гайновский, Антопольский и другие Райкомы КП(б)Б области обратить особое внимание на развертывание антирелигиозной пропаганды в предпраздничные и праздничные дни. Для этого организовать на предприятиях, в колхозах, селах, пшколах, избах-читальнях, клубах -- доклады, лекции, групповые и индивидуальные беседы о вреде и реакционной суцности пасхи и других религиозных праздников.

5. Обязать Гайновский и Антопольский РК КП(б)Б организовать в районах сбор материалов о деятельности религиозных организаций (церквей, костелов, синагог и религиозных сект) для разработки и пиирокого использования этих материалюв в антирелигиозной работе и раз- 
облачении контрреволюционной деятельности церковников и религиозных сект.

6. Имея факты неудовлетворительной постановки антирелигиозной работы в ряде других районов области (Клешельском, Малоритском, Дивинском, Ружанском и др.), Бюро Обкома КІІ(б)Б обязывает всех секретарей райкомов КП(б)Б обсудить на очередных заседаниях РК KII(б)Б решение ЦК КІІ(б)Б и Бюро Обкома об антирелигиозной работе и до 25/IV-41 г. информировать Обком партии о принятых мероприятиях по дальнейшему развертыванию антирелигиозной работы в районе.

7. IІредложить редактору Областной газеты «Зара» тов. Минчукову и редакторам районных газет регулярно помецать в газетах лекции, консультации, статьи на антирелигиозные темы, организовать обмен опытом антирелигиозной работы, разоблачая контрреволюционную деятельность духовенства и сектантов.

\section{СЕКРЕТАРЬ БРЕСТСКОГО ОБКОМА КІІ(б)Б (podpis)}

(М. ТУІІЦЫН $)^{1}$

/гк/

Obok podpisu okrągła pieczątka $\mathrm{z}$ następującym napisem w języku białoruskim: „Brzeski Obwodowy Komitet KP(b) Białorusi”.

Oryginal, maszynopis.

Źródło: PAOB w Brześciu, zesp. 17„P”, spr. 1, t. 10, k. 203-206.

a Podkreślenie i wielkie litery oryginału.

b Ten akapit został $w$ trakcie czytania zaznaczony $z$ lewej strony pionową linią.

1 Michaił Nikołajewicz Tupicyn, ur. w 1906 r., Rosjanin, wykształcenie średnie, nauczyciel. Do 1939 r. był I Sekretarzem KR. KP(b)B w Stolinie, następnie naczelnikiem Zarządu Obwodowego NKWD w Mozyrzu, w 1940 r. II Sekretarzem Komitetu Obwodowego KP(b)B w Białymstoku i od stycznia 1941 r. I Sekretarzem Komitetu Obwodowego w Brześciu. 